\title{
Cellular Trace Element Changes in Type 1 Diabetes Patients
}

\author{
Vahap Uğurlu1, Çiğdem Binay1, Enver Şimşek1, Cengiz Bal2 \\ 1 Osmangazi University Faculty of Medicine, Department of Pediatrics, Division of Pediatric Endocrinology, Eskişehir, Turkey \\ 2Osmangazi University Faculty of Medicine, Department of Medical Statistics, Eskişehir, Turkey
}

\section{WHAT IS ALREADY KNOWN ON THIS TOPIC?}

Magnesium $(\mathrm{Mg})$ is the most commonly seen trace element deficiency in patients with type I diabetes mellitus (TIDM). Moreover, $\mathrm{Mg}$ deficiency is involved in the pathogenesis of diabetes complications that inhibit the prostacyclin receptor function and cause increased thrombocyte activation and aggregation.

\section{WHAT THIS STUDY ADDS?}

Intra-erythrocyte $\mathrm{Mg}(\mathrm{eMg})$ measurement cannot reveal $\mathrm{Mg}$ deficiency, but increased retention following intravenous $\mathrm{Mg}$ tolerance test indicates intracellular $\mathrm{Mg}$ deficiency in patients with TIDM.

\section{ABSTRACT}

Objective: Type 1 diabetes mellitus (T1DM) may lead to deficiencies in trace elements that have substantial functions in the human organism. Changes in serum magnesium (Mg), copper (Cu), and zinc (Zn) levels are correlated with metabolic control and diabetes complications. The aim of this study was to evaluate the intraerythrocyte levels of trace elements and urinary $\mathrm{Mg}$ excretion following intravenous (iv) Mg tolerance testing in children with T1DM.

Methods: A total of 43 children aged 2-18 years with T1DM and age/gender-matched 25 healthy children were included in the study. The iv Mg tolerance test was performed following the measurement of intra-erythrocyte $\mathrm{Mg}\left(\mathrm{eMg}_{1}\right), \mathrm{Cu}(\mathrm{eCu})$, and $\mathrm{Zn}\left(\mathrm{eZn}_{1}\right)$ levels using the atomic absorption spectrophotometer method. The $\mathrm{Mg}$ retention ratio was estimated from measurements in $24 \mathrm{~h}$ urine samples.

Results: No statistically significant difference was found for $\mathrm{eMg}_{1}, \mathrm{eCu_{1 }}$, and $\mathrm{eZn} \mathrm{n}_{1}$ levels between the patient and control groups ( $p>0.05)$. In the patient group, the $\mathrm{eMg}_{1}$, $\mathrm{eCu} \mathrm{u}_{1}$, and $\mathrm{eZn} \mathrm{n}_{1}$ levels measured after the iv $\mathrm{Mg}$ tolerance test significantly increased compared with the baseline levels $(p<0.05)$, and the $\mathrm{Mg}$ excretion ratio measured from the urine collected after the iv $\mathrm{MgSO}_{4}$ infusion was $>50 \%$.

Conclusion: The increased retention value following the iv $\mathrm{Mg}$ tolerance testing indicates intracellular Mg deficiency in children with T1DM.

Key words: Type 1 diabetes mellitus, trace elements, magnesium tolerance test

Conflict of interest: None declared

Received: 28.09 .2015

Accepted: 16.01 .2016

\section{Introduction}

Type 1 diabetes mellitus (T1DM) is a chronic metabolic disease that occurs with increasing frequency in children. Recently, the effects of trace elements on glucose metabolism have been reported, suggesting their role in the etiopathogenesis and complications of diabetes $(1,2,3)$.

In many studies conducted on diabetic patients and experimental animals, zinc (Zn) has been reported to have positive

\section{Address for Correspondence}

Çiğdem Binay MD, Osmangazi University Faculty of Medicine, Department of Pediatrics, Division of Pediatric Endocrinology, Eskişehir, Turkey Phone: +90 5323771496 E-mail: cigdembinay@gmail.com

OJournal of Clinical Research in Pediatric Endocrinology, Published by Galenos Publishing. 
effects on hyperglycemia by increasing phosphoinoside-3 kinase activation, serine/threonine kinase phosphorylation, GLUT4 (glucose transporter type 4) translocation and insulin sensitivity and to enhance prevention of development of complications due to diabetes by decreasing oxidative stress $(4,5,6,7)$. Magnesium (Mg) is the most commonly seen trace element deficiency in patients with T1DM. Decreased plasma and tissue $\mathrm{Mg}$ levels have been reported among diabetic patients $(1,2,8)$. Mg plays an important role in whole reactions, including cellular energy transfer, glycolysis and phosphorylation, and it prevents free radical generation required to ensure increased glutathione syntheses (1). Moreover, $\mathrm{Mg}$ deficiency is involved in the pathogenesis of diabetes complications that inhibit the prostacyclin receptor function and cause increased thrombocyte activation and aggregation $(9,10)$. Body mineral values are ideally determined by measuring their tissue levels.

In the present study, we aimed to evaluate the tissue trace element levels by measuring the intra-erythrocyte $\mathrm{Mg}$ $\left(e \mathrm{Mg}_{1}\right), \mathrm{Zn}\left(\mathrm{eZn_{1 }}\right)$, and copper $\left(\mathrm{eCu_{1 }}\right)$ levels and the urinary Mg excretion level following the intravenous (iv) Mg tolerance test in children and adolescents diagnosed with T1DM in our pediatric endocrinology department.

\section{Methods}

Forty-three children and adolescents diagnosed with T1DM between June 2012 and March 2013 in the Department of Pediatric Endocrinology at Eskişehir Osmangazi University Faculty of Medicine (group 1) were included in the study. The inclusion criteria were as follows: (1) age under 18 years, (2) diagnosis of T1DM at least six months prior to admission, and (3) no concomitant disease apart from T1DM. The study also included 25 healthy children and adolescents without any chronic disease as a control group (group 2).

The study protocol was approved by the Ethics Committee of Osmangazi University Faculty of Medicine. Informed consent was obtained from all included children and their parents. A detailed physical examination was performed both in the study and control groups. Systolic/diastolic blood pressure (BP) was measured, and cases with a BP $\geq 95^{\text {th }}$ percentile were considered hypertensive (11). Body weight (BW) and height were measured in all cases. Height was measured by length gauge scale (Harpenden, Holtain, Crymych, UK), and BW was measured by portable scale (SECA 762; Vogel\&Halke, Hamburg, Germany). Body weight and height percentiles were estimated using the age- and gender-appropriate growth curves for Turkish children (12). Body mass index (BMI) was calculated as weight in kilograms divided by the square of length. Cases with $\geq 95^{\text {th }}$ percentile of BM were considered obese (13).

In both the study and control groups, following a 12-hour fasting period, baseline venous blood specimens were taken for determination of fasting blood glucose, urea nitrogen $(B \cup N)$, creatinine, calcium (Ca), phosphorus $(\mathrm{P})$, alkaline phosphatase (ALP), total cholesterol (TC), triglyceride (TG), low-density lipoprotein-cholesterol (LDL-C), high-density lipoprotein-cholesterol (HDL-C), and serum Mg levels. Blood specimens were also taken into $2 \mathrm{~mL}$ tubes containing EDTA for measurement of $\mathrm{eMg}_{1}, \mathrm{eZn_{1 }}$, and copper $\left(\mathrm{eCu_{1 }}\right)$ levels.

Hemoglobin $\mathrm{A} 1 \mathrm{c}(\mathrm{HbA} 1 \mathrm{c})$ levels were measured in all cases in the study group. $\mathrm{HbA} 1 \mathrm{c}$ levels of $6.06 \%-7.4 \%, 7.5 \%-9.0 \%$, and $>9.0 \%$ indicated satisfactory, mediocre, and poor control, respectively (14). Among the group 1 cases, retinal examination was performed by an ophthalmologist.

In group 1, the $24 \mathrm{~h}$ urine specimens were collected into plastic tubes that did not contain any metal for determination of microalbumin, creatinine, and urinary $\mathrm{Mg}\left(\mathrm{uMg}_{1}\right)$ levels. In the control group, urinary $\mathrm{Mg}$ level was estimated in spot urine samples.

Following the $24 \mathrm{~h}$ urine collection, the patient group was administered $0.2 \mathrm{mEq} / \mathrm{kg}$ of elemental $\mathrm{Mg}$. This was given as a $4 \mathrm{~h}$ iv infusion of a $15 \%$ magnesium sulfate $\left(\mathrm{MgSO}_{4}\right)$ in a $5 \%$ dextrose solution. For ethical reasons, iv $\mathrm{MgSO}_{4}$ was not given to the control group. In the patient group, for measurements of volume, creatinine, microalbumin, and $\mathrm{uMg}_{2}$ levels, $24 \mathrm{~h}$ urine specimens were again collected after starting the $\mathrm{MgSO}_{4}$ infusion. At the end of the second $24 \mathrm{~h}$ urine collection, $\mathrm{eMg}_{2}$, $\mathrm{eZn}_{2}$, and $\mathrm{eCu}_{2}$ levels were measured again. At the end of the
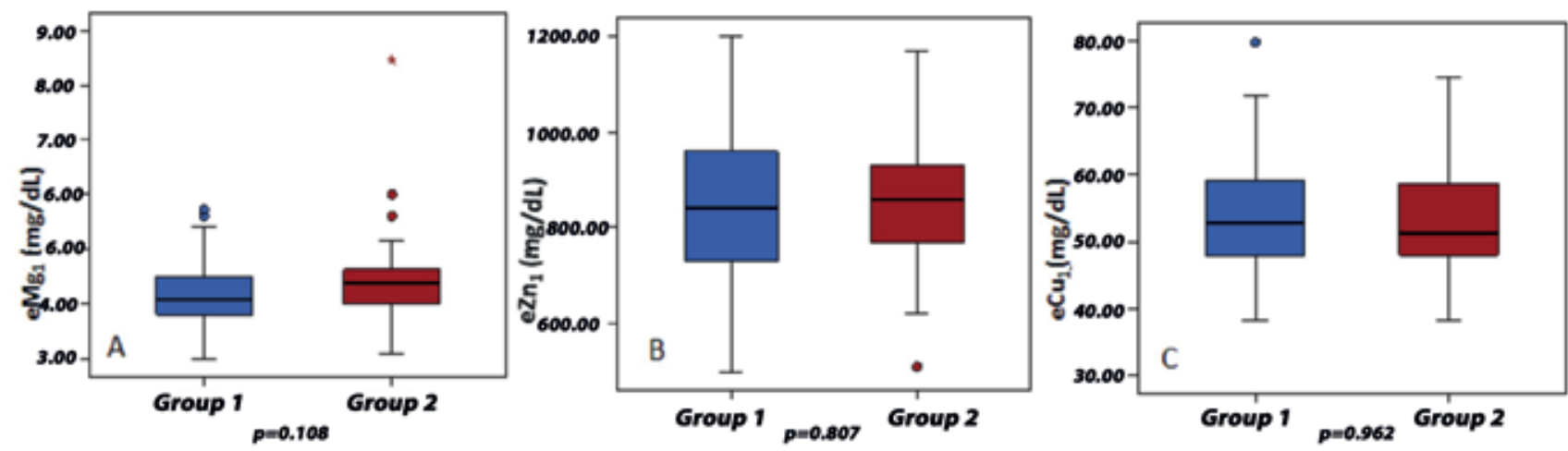

Figure 1. Intergroup (A) intra-erythrocyte magnesium, $(B)$ intra-erythrocyte zinc, and $(C)$ intra-erythrocyte copper levels 
iv $\mathrm{MgSO}_{4}$ infusion, $\mathrm{Mg}$ retention was estimated as follows (15):

Mg retention $(\%)=1-\frac{A-(B \times C)}{D} \times 100$

A: $M g$ level in $24 \mathrm{~h}$ urine after iv $\mathrm{MgSO}_{4}$

$\mathrm{B}$ : $\mathrm{Mg} /$ creatinine ratio in $24 \mathrm{~h}$ urine before iv $\mathrm{MgSO}_{4}$

$\mathrm{C}$ : Urinary creatinine level after iv $\mathrm{MgSO}_{4}$

D: Amount of total elemental Mg infusion

A $\mathrm{Mg}$ retention level of $>50 \%$ indicated deficiency. A possible Mg deficiency was considered when the Mg retention level was $25 \%-50 \%$. A normal Mg level was considered when the retention level was $<25 \%$.

\section{Laboratory Analysis}

$\mathrm{eMg}_{1}, \mathrm{eCu_{1 }}, \mathrm{eZn_{1 }}$, and urinary $\mathrm{Mg}$ levels were measured using the atomic absorption spectrophotometer (Analyst 100 Flame, Perkin-Elmer). Glucose, Ca, P, ALP, BUN, TG, HDL-C, LDL-C, and Mg levels were estimated using the enzymatic calorimetrical method with Roche Modular Equipment. Serum and $24 \mathrm{~h}$ urinary creatinine levels were measured using the kinetic colorimetric method, $\mathrm{HbA} 1 \mathrm{c}$ was measured using the turbidimetric inhibition method, and the microalbumin level was measured using the immune turbidimetric method in 24 h urine.

\section{Statistical Analysis}

Data were analysed using the Statistical Package for the Social Sciences 15.0 software for Windows (SPSS Inc., Chicago, IL, USA). The variable distribution was specified using the Kolmogorov-Smirnov test. The parametrical variables were expressed as mean \pm standard deviation, and the nonparametrical variables were expressed as median (minimummaximum). For intergroup comparison, the normally distributed variables were compared using independent samples t-test, and the non-normally distributed variables were compared using the Mann-Whitney U-test. For intragroup comparison, paired samples t-test and Wilcoxon rank test were performed, respectively. The inter-variable associations were determined by the Pearson and Spearman correlations. The intergroup comparison for the qualitative parameters was performed using the chi-square test. The cut-off value was estimated using the receiver operating characteristic $(\mathrm{ROC})$ curve analysis. $\mathrm{p}<0.05$ was considered statistically significant.

\section{Results}

Among the T1DM patients (group 1), 19 (44.2\%) were girls and 24 were boys (55.8\%). Mean age was $12.8 \pm 3.2$ years. In the control group (group 2), 17 (68\%) were girls and 8 were boys (32\%). Mean age was $12.4 \pm 4.5$ years. Table 1 shows the demographic and anthropometrical characteristics of the two groups. The patient group received insulin lispro three times daily and insulin glargine once a day, and the daily total insulin dose was $0.7 \mathrm{U} / \mathrm{kg} /$ day-1.5 U/kg/day. Of these patients, according to HbA1c levels, 4 (9.3\%) had well-controlled diabetes, 20 (46.5\%) had mediocre-controlled diabetes, and 19 (44.2\%) had poorly controlled diabetes.

No retinopathy was seen in the cases with T1DM. Fourteen of the cases (32.6\%) had nephropathy at the microalbuminuric level. Table 2 shows the comparison between serum Mg and other blood parameters by group. No significant difference was found in the baseline $\mathrm{eMg}_{1}, \mathrm{eZn_{1 }}, \mathrm{eCu_{1 }}$, and $\mathrm{uMg}_{1}$ levels between the two groups (Figure 1, Table 2). When the ROC curve analysis was performed for $\mathrm{eMg}_{1}, \mathrm{eZn}_{1}, \mathrm{eCu_{1 }}$, and $\mathrm{uMg}_{1}$, the area under curve was $0.613[p=0.073,95 \%$ confidence interval (Cl): 0.470-0.756] for $\mathrm{Mg}, 0.526(p=0.727,95 \% \mathrm{Cl}$ : $0.383-0.668$ ) for $\mathrm{Zn}$, and 0.488 ( $\mathrm{p}=0.869,95 \% \mathrm{Cl}: 0.345-0.631$ ) for $\mathrm{Cu}$. Based on these values, the cut-off was estimated as $4.21 \mathrm{mg} / \mathrm{dL}$ for $\mathrm{Mg}$ and $845 \mu \mathrm{g} / \mathrm{dL}$ for $\mathrm{Zn}$. When the normal and low levels were determined based on the cut-off values, the rate of low eMg${ }_{1}$ level was higher in group 1 than in group 2 . The rate of low e $Z n_{1}$ did not differ between the groups (Table 3 ).

Table 4 shows the $\mathrm{eMg}_{1}, \mathrm{Zn}$, and $\mathrm{Cu}$ levels before and after iv $\mathrm{MgSO}_{4}$ infusion in group 1 . These levels were significantly increased $(\mathrm{p}<0.001)$ after the iv $\mathrm{Mg}$ tolerance test. The $\mathrm{Mg}$ excretion ratio of $90.2 \pm 6.1 \%$ was measured from the urine collected after the iv $\mathrm{MgSO}_{4}$ infusion. In the study group, the overall ratio of $\mathrm{Mg}$ excretion was $>50 \%$.

No statistically significant difference was found in the $e \mathrm{Mg}_{1}, \mathrm{eZn_{1 }}, \mathrm{eCu_{1 }}$, and $\mathrm{uMg}_{1}$ levels among patients based on their diabetic metabolic control state according to $\mathrm{HbA} 1 \mathrm{c}$ levels ( $p>0.05)$, as shown in Table 5 . Mg excretion ratios were similar in patients with well-controlled $(89.3 \pm 6.9 \%)$ and poorly controlled $(91.3 \pm 4.5 \%)$ diabetes $(p=0.287)$. A positive correlation was found between $\mathrm{HbA} 1 \mathrm{c}$ and urinary microalbumin/creatinine ratios $(r=0.442, p=0.003)$. However, no statistically significant association was found between urinary microalbumin/creatinine ratios and $\mathrm{eMg}_{1}$ or $\mathrm{uMg}_{1}$ levels $(r=0.068, p=0.663$ and $r=0.044, p=0.780$, respectively).

\section{Discussion}

There is a growing interest for studies aiming to clarify the role of trace elements in the etiopathogenesis and complications of diabetes mellitus. The body reserve of trace elements is ideally measured at tissue level (16). Mg tolerance test is a reliable method that can well demonstrate the $\mathrm{Mg}$ level in tissue, but it requires short-term hospitalisation (17). In the present study, we found no statistically significant difference in the $\mathrm{eMg}_{1}$, $e \mathrm{n}_{1}$, and $\mathrm{eCu}_{1}$ levels between patients and control subjects. Multiple factors may lead to Mg deficiency in T1DM patients. Possibly, the most important mechanism is the urinary Mg loss resulting from osmotic diuresis due to the hyperglycemia. Taurine deficiency, changes in vitamin D metabolism, intestinal absorption inadequacy, defects in glutathione metabolism are the other important factors $(1,18,19)$. Recently, numerous studies have 
reported lower Mg levels in the plasma and tissue of diabetics $(1,2,8)$. In our study, although serum $\mathrm{Mg}$ and $\mathrm{eMg}_{1}$ levels were similar in both groups, $\mathrm{eMg}_{1}$ tended to be lower in patients with T1DM than in the controls. Consistent with our study, Rohn et al (19) did not find any significant difference in the $\mathrm{eMg}_{1}$ levels between patients and controls, but they found a similar tendency for Mg deficiency in patients with T1DM. Sjögren et al (20) reported that $\mathrm{eMg}_{1}$ measurement was inadequate in evaluating the total body $\mathrm{Mg}$ reserve and that intra-leukocyte muscle $\mathrm{Mg}$ measurement could be a better method. Resnick et al (21) examined intracellular Mg deficiency among diabetics and found significantly decreased serum ionised Mg levels in these patients. No significant difference was found in the $\mathrm{eMg}_{1}$ level and urinary Mg excretion between the two groups in our study. This finding may be due to the sufficient dietary Mg intake of the patient group included in this study. In some studies in which normal trace element levels were found among diabetics, this finding was also associated with sufficient dietary Mg intake $(22,23)$.

Table 1. Demographic and anthropometric characteristics in the study and control groups

\begin{tabular}{|l|l|l|l|}
\hline & $\begin{array}{l}\text { Group 1 } \\
(\mathbf{n = 4 3 )}\end{array}$ & $\begin{array}{l}\text { Group 2 } \\
(\mathbf{n = 2 5})\end{array}$ & $\mathbf{p}$ \\
\hline Age (years)* & $12.8 \pm 3.2$ & $12.4 \pm 4.5$ & 0.691 \\
\hline Gender (G/B) & $19 / 24$ & $17 / 8$ & 0.100 \\
\hline Weight SDS** & $0.22(-4-2.36)$ & $0.41(-1.24-2.43)$ & 0.294 \\
\hline Height SDS** & $-0.09(-3.48-2.23)$ & $0.41(-1.57-1.68)$ & 0.079 \\
\hline BMI SDS** & $0.32(-2.97-2.82)$ & $0.53(-1.33-2.22)$ & 0.824 \\
\hline Systolic BP (mmHg)** & $100(90-120)$ & $100(60-130)$ & 0.608 \\
\hline Diastolic BP (mmHg)** & $60(55-80)$ & 0.242 \\
\hline DM duration (years) & $60(50-80)$ & - & \\
\hline HbA1c (\%) & $2.5(0.5-17)$ & - & \\
\hline $\begin{array}{l}*: \text { mean } \pm \text { standard deviation, }{ }^{* *}: \text { median (minimum-maximum), G/B: girls/boys, SDS: standard deviation score, BMI: body mass index, BP: blood pressure, DM: diabetes mellitus, } \\
\text { HbA1c: glycated hemoglobin }\end{array}$ & $8.8(6.4-14.4)$ & \\
\hline
\end{tabular}

Table 2. Comparison of biochemical parameters by group

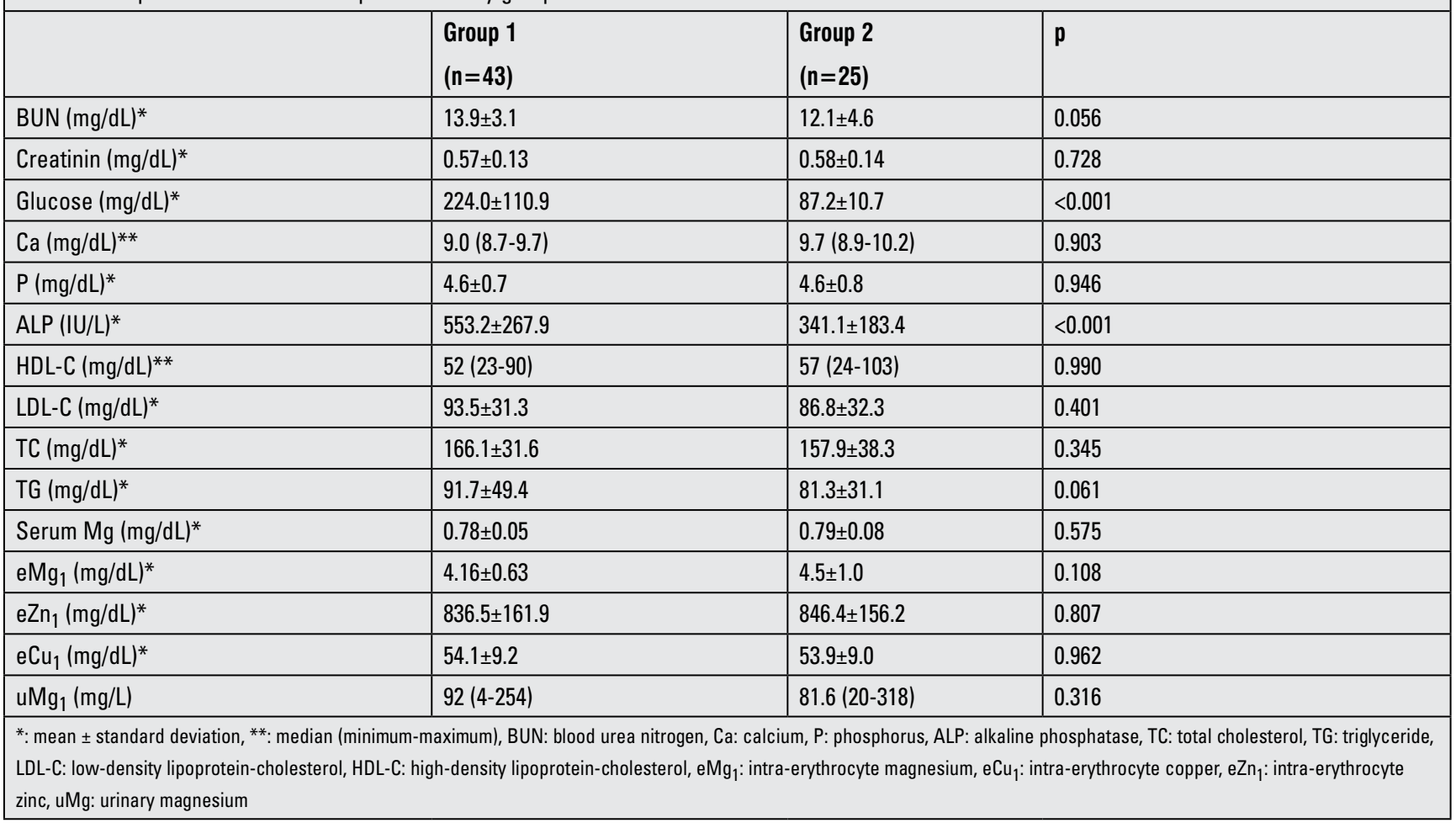


In some previous studies, Mg deficiency was implicated in the development of micro-and macro-vascular complications of diabetes $(8,24,25)$. Hypomagnesemia is known to be associated with dyslipidemia, inflammatory load, and increased oxidative stress (26). The serum Mg level was found to be low in diabetic patients with concomitant hypertension, ischemic heart disease (27), and severe diabetic retinopathy (28). Mg deficiency accelerated atherosclerosis and vascular damage in experimental animals, and it has been reported that $\mathrm{Mg}$ replacement decreased the development of atherosclerotic lesions, thus reducing serum cholesterol and triglyceride levels $(29,30)$. Atabek et al $(8)$ showed that Mg deficiency was related to atherosclerotic changes independent of lipid levels in children with T1DM. We did not find a significant association between urinary microalbumin/creatinine ratios and $\mathrm{eMg}_{1}$ or urinary microalbumin/creatinine ratios and $\mathrm{uMg}_{1}$ levels.

In the study of Schnack et al (31), serum and $\mathrm{eMg}_{1}$ levels were inversely correlated with metabolic control among diabetics. Such a correlation was not found in our study, and there were also no significant differences in $\mathrm{eMg}_{1}$ levels between the patient and the control groups. We therefore suggest that the measurement of the intra-erythrocyte or the urinary $\mathrm{Mg}$ level may be insufficient for evaluating the total body $\mathrm{Mg}$ reserve in diabetic patients. The results of Sjögren et al (20) who also did not find any correlation between $\mathrm{HbA} 1 \mathrm{c}$ and $\mathrm{eMg}_{1}$ or urinary $\mathrm{Mg}$ excretion, but found a significant correlation between muscle and the mononuclear intracellular $\mathrm{Mg}$ and $\mathrm{HbA} 1 \mathrm{c}$, support our suggestion.

In the present study, although the $\mathrm{eMg}_{1}$ level seems to be unaffected in diabetic patients, the mean urinary $\mathrm{Mg}$ retention of $90.2 \pm 6.1 \%$ and the significant increase in the $\mathrm{eMg}_{1}, \mathrm{Zn}$ and $\mathrm{Cu}$ levels following iv $\mathrm{MgSO}_{4}$ administration suggest an insufficient total body $\mathrm{Mg}$ reserve. Increased retention following the iv $\mathrm{MgSO}_{4}$ tolerance test is superior to other methods in demonstrating Mg deficiency $(32,33)$. Similarly, Simşek et al (15) found $>50 \% \mathrm{Mg}$ retention in $43 \%$ of patients with T1DM. By contrast, some studies found that increased urinary Mg excretion was not related to serum Mg concentration (34).

Mg shows multiple effects by acting on bone mineral homeostasis, on stabilisation of the crystal structure as well as on calcium metabolism and ALP efficiency. ALP is known

Table 3. Numbers (ratios) of decreased intra-erythrocyte magnesium and intra-erythrocyte zinc levels by group

\begin{tabular}{|l|l|l|l|l|}
\hline \multicolumn{2}{|l|}{} & Group 1 & Group 2 & p \\
\hline $\mathrm{eMg}_{1}$ & Normal & $17(39.5 \%)$ & $17(68 \%)$ & \multirow{2}{*}{0.024} \\
\cline { 2 - 5 } & Low & $26(60.5 \%)$ & $8(32 \%)$ & \multirow{2}{*}{0.700} \\
\hline \multirow{2}{*}{ eZn 1} & Normal & $22(51.2 \%)$ & $14(56 \%)$ & $11(44 \%)$ \\
\cline { 2 - 5 } & Low & $21(48.8 \%)$ & & \\
\hline eMg $:$ intra-erythrocyte magnesium, eZn 1 intra-erythrocyte zinc
\end{tabular}

Table 4. Intra-erythrocyte trace element levels before and after iv magnesium infusion in the patient group

\begin{tabular}{|l|l|l|l|}
\hline & $\begin{array}{l}\text { Before } \\
\text { iv magnesium }\end{array}$ & $\begin{array}{l}\text { After } \\
\text { iv magnesium }\end{array}$ & p \\
\hline Magnesium $_{\text {erythrocyte }^{*}(\mathrm{mg} / \mathrm{dL})^{*}}$ & $4.16 \pm 0.63$ & $4.32 \pm 0.65$ & $<0.001$ \\
\hline Zinc $_{\text {erythrocyte* }}(\mathrm{mg} / \mathrm{dL})^{*}$ & $836.5 \pm 161.9$ & $855.1 \pm 182.0$ & $<0.001$ \\
\hline Copper $_{\text {erythrocyte* }}(\mathrm{mg} / \mathrm{dL})^{*}$ & $54.1 \pm 9.2$ & $54.3 \pm 8.7$ & $<0.001$ \\
\hline Magnesium $_{\text {urine* }}(\mathrm{mg} /$ day) & $134.8 \pm 73.2$ & $289.1 \pm 138.6$ & $<0.001$ \\
\hline *: paired sample t-test, iv: intravenous & & \\
\hline
\end{tabular}

Table 5. Differences in trace element levels by state of metabolic control

\begin{tabular}{|l|l|l|l|}
\hline & $\begin{array}{l}\text { Well-mediocre controlled } \\
(\mathbf{n = 2 4 )}\end{array}$ & $\begin{array}{l}\text { Poorly controlled } \\
(\mathbf{n = 1 9 )}\end{array}$ & $\mathbf{p}$ \\
\hline Magnesium $_{\text {erythrocyte* }(\mathrm{mg} / \mathrm{dL})^{*}}$ & $4.2 \pm 0.5$ & $4.1 \pm 0.7$ & 0.633 \\
\hline Zinc $_{\text {erythrocyte }^{*}(\mathrm{mg} / \mathrm{dL})^{*}}$ & $827.9 \pm 162.1$ & $847.3 \pm 165.4$ & 0.701 \\
\hline Copper $_{\text {rrythrocyte* }^{*}(\mathrm{mg} / \mathrm{dL})^{*}}$ & $54.6 \pm 8.4$ & $53.2 \pm 10.3$ & 0.627 \\
\hline Magnesium $_{\text {urine* }}(\mathrm{mg} / \mathrm{day})$ & $140.5 \pm 74.8$ & $127.5 \pm 72.4$ & 0.572 \\
\hline *: paired sample t-test & & \\
\hline
\end{tabular}


to express during the early stage of stiff bone tissue formation in bone and calcified cartilage. Although the effects of ALP on bone mineralisation are not fully understood, ALP is considered to enable the increase in inorganic phosphate (35). In our study, while the intracellular increase in trace elements after iv $\mathrm{MgSO}_{4}$ application indicated total body deficiency, a statistically significant increase in ALP supported the presence of such a deficiency in the diabetic group. ALP may increase to provide adequate functioning during $\mathrm{Mg}$ deficiency when the major portion of the $\mathrm{Mg}$ is present in the bone tissue. These results suggested that $\mathrm{eMg}_{1}$ level remained incapable to demonstrate the total body $\mathrm{Mg}$ concentration in diabetic patients.

In conclusion, $\mathrm{eMg}_{1}$ measurement cannot reveal $\mathrm{Mg}$ deficiency, but increased retention following iv Mg tolerance test indicates intracellular $\mathrm{Mg}$ deficiency in patients with T1DM. Moreover, if $\mathrm{Mg}$ deficiency is detected by the $\mathrm{Mg}$ retention test, which should be performed at least once a year, then $\mathrm{Mg}$ replacement therapy may help to provide glycemic control in poorly controlled T1DM patients.

\section{Ethics}

Ethics Committee Approval: The study protocol was approved by the Ethics Committee of Osmangazi University Faculty of Medicine, Informed Consent: Informed consent was obtained from all included children and their parents.

Peer-review: External peer-reviewed.

\section{Authorship Contributions}

Concept: Enver Şimşek, Design: Enver Şimşek, Data Collection or Processing: Vahap Uğurlu, Çiğdem Binay, Enver Şimşek, Analysis or Interpretation: Cengiz Bal, Enver Şimşek, Vahap Uğurlu, Çiğdem Binay, Literature Search: Vahap Uğurlu, Çiğdem Binay, Writing: Vahap Uğurlu, Çiğdem Binay, Enver Şimşek.

Financial Disclosure: The authors declared that this study received no financial support.

\section{References}

1. Salmonowicz B, Krzystek-Korpacka M, Noczyńska A. Trace elements, magnesium, and the efficacy of antioxidant systems in children with type 1 diabetes mellitus and in their siblings. Adv ClinExp Med 2014;23: 259-268.

2. Wegner $M$, Araszkiewicz $A$, Zozulińska-Ziółkiewicz $D$, Wierusz-Wysocka B, Pioruńska-Mikołajczak A, PioruńskaStolzmann M. The relationship between concentrations of magnesium and oxidized low density lipoprotein and the activity of platelet activating factor acetylhydrolase in the serum of patients with type 1 diabetes. Magnes Res 2010;23:97-104. Epub 2010 May

3. Galli-Tsinopoulou A, Maggana I, Kyrgios I, Mouzaki K, Grammatikopoulou MG, Stylianou C, Karavanaki K. Association between magnesium concentration and $\mathrm{HbA} 1 \mathrm{c}$ in children and adolescents with type 1 diabetes mellitus. J Diabetes 2014;6:369-377. Epub 2014 Feb 24

4. Valko M, Morris H, Cronin MT. Metals, toxicity and oxidative stress.Curr Med Chem 2005;12:1161-1208.
5. Chen MD, Song YM, Lin PY. Zinc effects on hyperglycemia and hypoleptinemia in streptozotocin-induced diabetic mice. Horm Metab Res 2000;32:107-109.

6. Moustafa SA. Zinc might protect oxidative changes in the retina and pancreas at the early stage of diabetic rats. Toxicol Appl Pharmacol 2004;201:149-155.

7. Faure P, Benhamou PY, Perard A, Halimi S, Roussel AM. Lipid peroxidation in insulin-dependent diabetic patients with early retina degenerative lesions: effects of an oral zinc supplementation. Eur J ClinNutr 1995;49:282-288.

8. Atabek ME, Kurtoglu S, Pirgon O, Baykara M. Serum magnesium concentrations in type 1 diabetic patients: relation to early atherosclerosis. Diabetes Res Clin Pract 2006;72:42-47. Epub 2005 Oct 7

9. Nadler JL, Rude RK. Disorders of magnesium metabolism. Endocrinol Metab Clin North Am 1995;24:623-641.

10. Nadler JL, Malayan S, Luong H, Shaw S, Natarajan RD, Rude RK. Intracellular free magnesium defýciency plays a key role in increased platelet reactivity in type $\|$ diabetes mellitus. Diabetes Care 1992;15:835-841.

11. National High Blood Pressure Education Program Working Group on High Blood Pressure in Children and Adolescents. The fourth report on the diagnosis, evaluation, and treatment of high blood pressure in children and adolescents. Pediatrics 2004;114:555-576.

12. Neyzi O, Furman A, Bundak R, Gunoz H, Darendeliler F, Bas F. Growth references for Turkish children aged 6 to 18 years. Acta Paediatrica 2006;95:1635-1641.

13. Bundak R, Furman A, Gunoz H, Darendeliler F, Bas F, Neyzi O. Body mass index references for Turkish children. Acta Paediatrica 2006;95:195-198.

14. Rewers M, Pihoker C, Donaghue K, Hanas R, Swift $P_{\text {, }}$ Klingensmith GJ. Assessment and monitoring of glycemic control in children and adolescents with diabetes. Pediatr Diabetes 2009;(10Suppl 12):71-81.

15. Simşek E, Karabay M, Kocabay K. Assessment of magnesium status in newly diagnosed diabetic children: measurement of erythrocyte magnesium level and magnesium tolerance testing. Turk J Pediatr 2005;47:132-137.

16. Kruse-Jarres JD, Rükgauer M. Trace elements in diabetes mellitus. Peculiarities and clinical validity of determinations in blood cells. J Trace Elem Med Biol 2000;14:21-27.

17. Swaminathan R. Magnesium metabolism and its disorders. Clin Biochem Rev 2003;24:47-66.

18. Johansson G, Danielsson BG, Ljunghall S, Wibell L. Evidence for a disturbed magnesium metabolism in diabetes mellitus. Magnesium Bull 1982;3:178-180.

19. Rohn RD, Pleban P, Jenkins LL. Magnesium, zinc and copper in plasma and blood cellular components in children with IDDM. Clin Chim Acta 1993;215:21-28.

20. Sjögren A, Floren $\mathrm{CH}$, Nilson A. Magnesium deficiency in IDDM related to level of glycosylated hemoglobin. Diabetes 1986;35:459-463.

21. Resnick LM, Altura BT, Gupta RK, Laragh JH, Alderman $\mathrm{MH}$, Altura BM. Inracellular and extracellular magnesium depletion in type 2 (non insülin dependent) diabetes mellitus. Diabetologia 1993;36:767-770. 
Uğurlu $V$ et al.

Trace Element Changes in Type 1 Diabetes Mellitus

22. Zargar AH, Bashir MI, Masoodi SR, Laway BA, Wani Al, Wani Al, Khan AR, Dar FA. Copper, zinc and magnesium levels in type-1 diabetes mellitus. Saudi Med J 2002;23:539-542.

23. Derakhshan R, Balaee P, Darakhshan S, Masoodpoor N, Banihosseini SS. Lipid profile, thyroid function, and serum magnesium level in type I diabetic children. Minerva Pediatr 2011;63:27-33.

24. Walter RM Jr, Uriu-Hare JY, Olin KL, Oster MH, Anawalt BD, Critchfield JW, Keen CL. Copper, zinc, magnesium status and complications of diabetes mellitus. Diabetes Care 1991;14:1050-1056.

25. Mather HM, Levin GE, Nisbet JA. Hypomagnesemia and symptomaticischemic heart disease in diabetes. Magnesium Bull 1981;3:169-172.

26. Masharani U, German MS. Pancreatic hormones and diabetes mellitus. In: Gardner DG, Shoback D (eds). Greenspan's Basic and Clinical Endocrinology, 9th ed. New York, USA, McGraw-Hill, 2011:573-655.

27. Seelig MS, Heggtviet HA. Magnesium interrelationships in ischemic heart disease, a review. Am J Clin Nutr 1974;27:59-79.

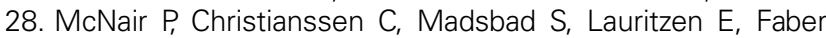
O, Binder C, Transbøl I. Hypomagnesemia, a risk factor in diabetic retinopathy. Diabetes 1978;27:1075-1077.
29. Altura BM, Altura BT. Role of magnesium in the pathogenesis of hypertension updated: relationship to its action on cardiac, vascular smooth muscle and endothelial cells. in: J.H LaraghB.M Brenner (Eds.) Hypertension: Pathophysiology, Diagnosis, and Management. 2nd ed. Raven Press, New York; 1995. pp.1213-1242.

30. Saris NE, Mervaala E, Karppanen H, Khawaja JA, Lewenstam A. Magnesium. An update on physiological, clinical and analytical aspects. Clin Chim Acta 2000;294:1-26.

31. Schnack CH, Bauer I, Oregnant $P$, Hopmeier $P$, Schernthaner G. Hypomagnesemia in type 2 (non insulin dependent) diabetes mellitus is not corrected by improvoment of long term metabolic control. Diabetologia 1992;35:77-79.

32. Elin RJ. Magnesium: the fifth but forgotten electrolyte. Am J ClinPathol 1994;102:616-622.

33. Cohen I, Laor A. Correlation between bone magnesium concentration and magnesium retention in the intravenous magnesium load test. Magnes Res 1990;3:271-274.

34. Chen MD, Lin PY, Tsou CT, Wang JJ, Lin WH. Selected metals status in patients with non-insulin-dependent diabetes mellitus. Biol Trace Elem Res 1995;50:119-124.

35. Golub EE, Kathleen BB. The role of alkaline phosphatase in mineralization. Curr Opin Orthop 2007;2:157-163. 